\title{
Comunicação
}

[Communication $]$

\section{PCR duplex para diferenciação de amostras vacinais e selvagens do vírus da doença de Aujeszky}

[A duplex PCR for differentiation of wild and vaccine virus of Aujeszky's disease]

\author{
A.A. Fonseca Jr ${ }^{1}$, N.L. Dias ${ }^{1}$, R.C. Leite ${ }^{2}$, M.B. Heinemann ${ }^{2}$, J.K.P. Reis ${ }^{2}$ \\ ${ }^{1}$ Laboratório Nacional Agropecuário - MAPA \\ Av. Rômulo Joviano, s/n \\ Caixa Postal 50 \\ 33600-000 - Pedro Leopoldo, MG \\ ${ }^{2}$ Escola de Veterinária - UFMG - Belo Horizonte, MG
}

A doença de Aujeszky (DA) é uma enfermidade de grande relevância na suinocultura, sendo de notificação obrigatória pela Organização Mundial de Saúde Animal (OIE, 2009). Sua importância não se dá apenas pelo impacto econômico causado pelo elevado índice de letalidade em leitões, mas também por barreiras sanitárias na exportação de carne suína (Bascuñana et al., 1997). O agente etiológico da DA é o herpesvírus suíno 1 (SuHV-1), classificado como um membro da família Herpesviridae, subfamília Alphaherpesvirinae, gênero Varicellovirus (Pomeranz et al., 2005).

Nos suínos, a DA é caracterizada pelos sinais neurológicos e elevada letalidade em animais jovens. Em animais mais velhos, a letalidade diminui, porém há uma alta morbidade e a predominância de sinais respiratórios. Todo suíno sobrevivente poderá ser considerado um portador latente, tornando-se uma fonte de infecção quando o vírus é reativado devido à imunossupressão normalmente desencadeada por estresse ambiental (Pomeranz et al., 2005).

Um dos principais métodos de controle da DA é a vacinação utilizando vírus atenuados deletados para uma das glicoproteínas do SuHV-1. A glicoproteína $\mathrm{E}(\mathrm{gE})$ é comumente deletada nessas amostras, de modo que animais vacinados possam ser posteriormente diferenciados por testes sorológicos (Dambros et al., 2007). Apesar da especificidade dos testes baseados na detecção de anticorpos, como ELISA e soroneutralização, eles têm a desvantagem de depender da

Recebido em 30 de março de 2010

Aceito em 29 de setembro de 2010

E-mail: augustofj@yahoo.com.br

Apoio: INCT-IGSPB CNPq e LANAGRO/MG - MAPA. soroconversão do animal. A utilização desses testes durante a fase aguda da doença pode levar a resultados falso-negativos, pois são necessários pelo menos 10 dias, em média, para a detecção dos anticorpos específicos (Kinker et al., 1997). Animais mais jovens podem morrer antes da soroconversão, inviabilizando o diagnóstico sorológico (Kinker et al., 1997). O problema não se resume somente à fase aguda da infecção, pois animais portadores do vírus latente podem apresentar decaimento do nível de anticorpos, acarretando também resultados falso-negativos (McCaw et al., 1997).

Em 2007, um Plano de Erradicação da Doença de Aujeszky foi aprovado pelo Ministério da Agricultura Pecuária e Abastecimento (MAPA Brasil, 2007). A vacinação é permitida no Brasil somente em casos de focos confirmados, sendo permitido o uso de vacinas atenuadas $\mathrm{e}$ inativadas, desde que não produzam anticorpos para gE. O plano também preconiza a proibição do trânsito de animais vacinados, a menos que seja para o abate.

O objetivo deste trabalho foi padronizar uma PCR duplex para diferenciação do vírus vacinal do vírus selvagem, visto que a PCR pode ser uma ferramenta importante não só para o diagnóstico da enfermidade, mas também por permitir a diferenciação de animais reativos que não puderam ser discriminados pelos testes sorológicos (Bascuñana et al., 1997).

A estirpe padrão Shope e a vacinal Bartha foram utilizadas para padronização da técnica. A 
amostra Shope foi titulada em células de rim de suíno (PK15), obtendo-se o resultado de $10^{4,5}$ TCID50/50 $\mu \mathrm{L}$. Após a padronização, a PCR foi avaliada em amostras clínicas. Dez amostras de cérebro de suínos positivos para SuHV-1, por meio do isolamento e identificação em cultivo celular segundo recomendação do manual da OIE (2009), foram utilizadas neste trabalho. Outras 20 amostras de cérebro de suíno de rebanhos livres do SuHV-1 foram colhidas em um abatedouro e submetidas ao isolamento viral (OIE, 2009), e todas elas foram consideradas negativas em trabalhos anteriores (Fonseca Jr. et al., 2010a). A extração de DNA foi realizada pelo método descrito por Sambrook et al. (1989).

Os alvos da PCR duplex foram a glicoproteína $\mathrm{E}$ (gE) e a glicoproteína B (gB), sendo gB altamente conservada e essencial para a replicação do vírus (Pomeranz et al., 2005). A mistura da PCR duplex foi constituída de: 6 pmoles de cada iniciador para gB (gBF 5'GAACCTGACGCTGCTGGAGGACCGACCG3' e gBR 5'AGGCCCTGGAAGAAG'ITGGCGATGCATGC3' (Bascuñana et al., 1997)) (IDT, Estados Unidos), 7,5pmoles de cada iniciador para $\mathrm{gE}$ (gEF 5'CCGCGGGCCGTGTTCTTTGT3' e gER 5'CGTGGCCGTTGTGGGTCAT3' (Huang et al., 2004)) (IDT, USA), 2U de Taq DNA Polimerase Platinum (Invitrogen, Estados Unidos), $2 \mu \mathrm{L}$ de Tampão 10x, MgCl2 1.5mmol/L, $6 \%$ de DMSO, DNTP 200 $\mu \mathrm{mol} / \mathrm{L}$ (Invitrogen, Estados Unidos). As condições utilizadas para a PCR duplex foram as seguintes: um estágio de desnaturação a $95^{\circ} \mathrm{C}$ por $5 \mathrm{~min}, 35$ ciclos a $95^{\circ} \mathrm{C}$ por $45 \mathrm{~s}, 60^{\circ} \mathrm{C}$ por $45 \mathrm{~s}, 72^{\circ} \mathrm{C}$ por $15 \mathrm{~s}$ e um estágio final de extensão a $72^{\circ} \mathrm{C}$ por $5 \mathrm{~min}$. O tamanho do fragmento para o gene gB foi de $207 \mathrm{pb}$ e para $\mathrm{gE}$ de 498pb.

A determinação da sensibilidade analítica da PCR duplex foi realizada com a estirpe padrão Shope como descrito por Fonseca Jr. et al. (2010a). Nove isolados de campo do SuHV-1 previamente caracterizados (Fonseca Jr. et al., 2010b) foram utilizados para verificar se os iniciadores eram capazes de detectar cepas dos vírus circulantes no Brasil. Também foi utilizada a amostra NIA-4 que é deletada para gE. O DNA foi extraído conforme descrito anteriormente.

A PCR duplex foi capaz de diferenciar a amostra vacinal Bartha da amostra padrão Shope. Visualiza-se apenas uma banda de 207pb, referente ao gene codificante de $\mathrm{gB}$, quando a estirpe Bartha é submetida à reação. A cepa padrão Shope apresenta um perfil com duas bandas, resultado da amplificação dos genes de gB e gE com os tamanhos de 207pb e 498pb, respectivamente (Fig. 1A). Todas as amostras clínicas positivas amplificaram para os dois genes na PCR duplex (Fig. 1B). Não houve a formação de bandas inespecíficas nos testes das amostras negativas (Fig. 1A e B).

A sensibilidade analítica da técnica foi de $10^{0,5}$ TCID50/50 $\mu \mathrm{L}$ em cérebro de suíno (Fig. 1B). Não houve nenhuma ausência de amplificação nesse limite. Uma reação com concentração de vírus correspondente a $10^{-1,5}$ TCID50/50 $\mu \mathrm{L}$ amplificou em apenas uma das três repetições.

Todas os isolados testados amplificaram para ambos os genes, gB e gE na PCR duplex, sem demonstrarem divergências nos tamanhos das bandas. A amostra NIA-4 apresentou um perfil de amplificação idêntico ao da estirpe vacinal Bartha, como esperado. A utilização de dois pares de iniciadores para amplificação das duas regiões gênicas em estudo diminuiu a sensibilidade da PCR duplex em cerca de 10 vezes.

O diagnóstico de enfermidades virais tem como teste de referência, em sua maioria, o isolamento do agente infeccioso em sistemas celulares (OIE, 2009). Para a DA, a OIE (2009) aconselha em seu manual de diagnóstico, sempre que possível, a utilização do isolamento viral. Essa técnica, no entanto, tem como desvantagens a necessidade do cultivo de células de linhagem contínua e o fato de contar com o vírus ainda ativo. Outros problemas dificultam o processo, como as várias passagens e o risco de contaminação dos cultivos celulares com bactérias e fungos presentes na própria amostra clínica. Os métodos imunológicos são uma boa alternativa para esse diagnóstico, porém estão sujeitos a resultados falso-negativos quando os animais ainda estão na fase aguda da infecção ou quando ocorre queda do título de anticorpos na infecção latente (McCaw et al., 1997). Caso o animal morra antes da soroconversão, as técnicas sorológicas não são de grande valia. Nesses casos, a PCR duplex é uma alternativa importante no laboratório de diagnóstico. 


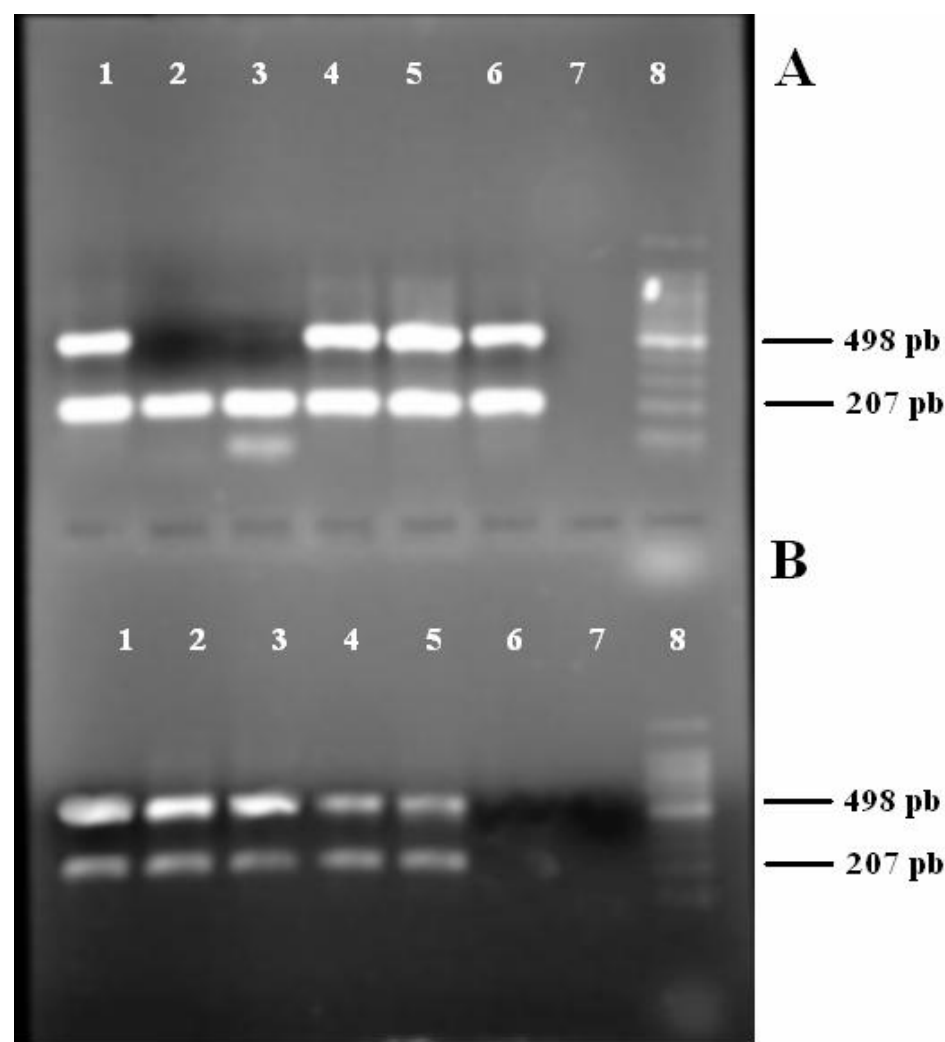

Figura 1. Resultado da PCR duplex em gel de agarose 1,5\% corado com brometo de etídeo. A: 1 amostra padrão Shope; 2 - amostra vacinal Bartha; 3 - isolado de campo NIA-4; 4 - amostra clínica; 5 isolado de campo 031; 6 - isolado de campo F3319; 7 - controle negativo; 8 - marcador de tamanho molecular. B: determinação da sensibilidade analítica: $1-10^{4,5}$ TCID50/50 $\mu \mathrm{L} ; 2-10^{3,5}$ TCID50/50 $\mu \mathrm{L} ; 3$ $-10^{2,5}$ TCID50/50 $\mu \mathrm{L} ; 4-10^{1,5}$ TCID50/50 $\mu \mathrm{L} ; 5-10^{0,5}$ TCID50/50 $\mu \mathrm{L} ; 6-10^{-1,5}$ TCID50/50 $\mu \mathrm{L} ; 7-10^{-2,5}$ TCID50/50 $\mu \mathrm{L}, 8$ - marcador de tamanho molecular.

O Plano de Erradicação da DA do MAPA determina que apenas vacinas deletadas para $\mathrm{gE}$ podem ser utilizadas nos focos (Brasil, 2007). Além da diferenciação de amostras vacinais e selvagens, a PCR duplex desenvolvida neste trabalho pode ser utilizada para estudar o risco de difusão do vírus vacinal nos rebanhos, sendo, portanto, uma ferramenta importante até mesmo em questões de biossegurança. As vacinas vivas, apesar de mais eficientes em sua proteção, oferecem risco por ainda serem infectantes.

O SuHV-1 é um vírus geneticamente estável, no entanto existem dois genótipos distintos no Brasil, o genótipo I e o II (Fonseca Jr. et al., 20010b). Amostras desses genótipos foram testadas e todas amplificaram com perfil idêntico ao do padrão Shope, indicando que a PCR duplex é capaz de detectar os vírus circulantes no país a despeito dos polimorfismos nos genes utilizados na PCR dúplex.
A detecção de animais únicos reativos (animais infectados que reagem nos testes imunológicos de diferenciação vacinal, mas não no de triagem) é importante nos programas de erradicação e na certificação de granjas. Esse fenômeno foi descrito nos Estados Unidos, Holanda, Alemanha, Reino Unido e Suécia (Bascuñana et al., 1997). PCRs convencionais foram utilizadas para a confirmação do diagnóstico em todos esses casos. A utilização da PCR duplex economiza tempo e reagentes ao distinguir vírus selvagens de vírus vacinal com apenas uma reação.

Outros autores salientaram a importância da PCR no diagnóstico da DA (Yoon et al., 2006). À medida que os programas de erradicação avançam, as normas sobre manipulação dos agentes infecciosos tornam-se mais rígidas. Em estágios mais avançados dos programas de erradicação, o isolamento viral não é 
aconselhado, a não ser em ambientes com alto nível de biossegurança. A PCR duplex padronizada neste trabalho é, então, uma ferramenta alternativa muito útil e de custo baixo para detecção e diferenciação do SuHV-1. Além disso, seus produtos ainda podem ser utilizados em sequenciamento para análises de epidemiologia molecular.
A PCR duplex padronizada para detecção e diferenciação de SuHV-1 vacinal e selvagem foi sensível, sendo que a técnica molecular é menos trabalhosa que o isolamento e pode ser utilizada tanto como rotina de diagnóstico quanto ferramenta auxiliar na presença de resultados inconclusivos nas provas sorológicas.

Palavras-chave: doença de Aujeszky, PCR, vacina

\begin{abstract}
A duplex PCR was developed to differentiate the wild-type virus from the attenuated virus used in vaccinations. The PCR was able to amplify fragments of $493 \mathrm{bp}$ for glycoprotein $E(\mathrm{gE})$ gene and $207 \mathrm{bp}$ for glycoprotein $B$ (gB) gene. The analytical sensitivity was determined by addition of a virus field sample titled in the brain samples of pigs. The standard virus strain Shope, the vaccine strain Bartha, and ten other field isolates were subjected to PCR. The PCR was able to amplify fragments of $\mathrm{gE}$ and $\mathrm{gB}$ in all field samples and only fragments of $\mathrm{gB}$ were amplified in the attenuated virus, as expected. The technique was able to detect up to $10^{0.5}$ TCID50/50 $\mu$ L virus in samples of brain. Duplex PCR proved to be an important tool for differentiation of naturally-infected animals and animals vaccinated with the virus deleted for $\mathrm{gE}$.
\end{abstract}

Keywords: Aujeszky's disease, PCR, vaccine

\section{REFERÊNCIAS BIBLIOGRÁFICAS}

BASCUÑANA, C.R.; BJÖRNEROT, L.; BALLAGIPORDÁNY, A. et al. Detection of pseudorabies virus genomic sequences in apparently uninfected "single reactor" pigs. Vet. Microbiol., v.55, p.37-47, 1997.

BRASIL. Ministério da Agricultura Pecuária e Abastecimento. Instrução Normativa ${ }^{\circ} 8$ de 3 de abril de 2007. Aprova as Normas para o Controle e a Erradicação da Doença de Aujeszky (DA) em suídeos domésticos, a serem observadas em todo o território nacional. Brasília, DF: Diário Oficial da União. Seção 1, Página 1, 10 de abril de 2007.

DAMBROS, R.M.F.; RIBEIRO, B.M.; AGUIAR, R.W.S. et al. Cloning and expression of Aujeszky's disease virus glycoprotein $\mathrm{E}(\mathrm{gE})$ in a baculovirus system. Braz. J. Microbiol., v.38, p.494-499, 2007.

FONSECA Jr., A.A.; CAMARGOS, M.F.; CIACCIZANELLA, J.R. et al. Diagnóstico e genotipagem do vírus da pseudoraiva por nested-PCR e análise de restrição enzimática. Cienc. Rural, v.40, p.921-927, 2010a.

FONSECA Jr., A.A.; CAMARGOS, M.F.; DE OLIVEIRA, A.M. et al. Molecular epidemiology of Brazilian pseudorabies viral isolates. Vet. Microbiol., v.141, p.238-245, 2010b.

HUANG, C.; HUNG, J.J.; WU, C.Y. et al. Multiplex PCR for rapid detection of pseudorabies virus, porcine parvovirus and porcine circoviruses. Vet. Microbiol., v.101, p.209-14, 2004
KINKER, D.R.; SWENSON, S.L.; WU, L.L. et al. Evaluation of serological tests for the detection of pseudorabies gE antibodies during early infection. Vet. Microbiol., v.55, p.99-106, 1997.

McCAW, M.B.; OSORIO, F.A.; WHEELER, J. et al. Effect of maternally acquired Aujeszky's disease (pseudorabies) virus-specific antibody in pigs on establishment of latency and seroconversion to differential glycoproteins after low dose challenge. Vet. Microbiol., v.55, p.91-98, 1997.

OIE. World Organisation for Animal Health. Manual of diagnostic tests and vaccines for terrestrial animals. 5th ed. Paris: OIE, 2009. <Disponível em: http://www.oie.int/eng/normes/mmanual/A_summry.htm>. Acessado em: $10 \mathrm{dez} 2009$.

POMERANZ, L.E.; REYNOLDS, A.E.; HENGARTNER, C.J. Molecular biology of pseudorabies virus: impact on neurovirology and veterinary medicine. Microbiol. Mol. Biol. Rev., v.69, p.462-500, 2005.

SAMBROOK, J.; FRITSCH, E.F.; MANIATIS, T. Molecular cloning: A laboratory manual. 2.ed. New York: Cold Spring Harbor, 1989.

YOON, H.A.; EO, S.K.; ALEYAS, A.G. et al. Investigation of pseudorabies virus latency in nervous tissues of seropositive pigs exposed to field strain. $J$. Vet. Med. Sci., v.68, p.143-148, 2006. 